\title{
Influence of Work-Family Conflict and Work Stress on the Psychological Well-Being among Police Officers in Makurdi Metropolis.
}

\author{
Shide Sunday \\ Department of Psychology \\ Benue State University, Makurdi. \\ Anhange Samuel Terzungwe (Ph.D) \\ Department of Psychology \\ Benue State University, Makurdi. \\ S. Okhakhume (Ph.D) \\ Department of Psychology \\ Benue State University, Makurdi. \\ Daudu Amough Daudu \\ Department of Psychology \\ Benue State University, Makurdi.
}

\begin{abstract}
This study investigated the influence of work-family conflict and work stress on the psychological well-being among police Officers in Makurdi metropolis. The study employed a cross-sectional survey design, where three hundred and fourty six (346) police Officers consisting of $202(58.7 \%)$ males and $143(41.3 \%)$ females were used for the study. Their ages ranged from 18 to 64 years with the Mean of 411.61 (SD=11.226). Work- Family Conflict Scale (WFCS), Workplace Stress Scale (WSS) and Ryff's Psychological Well-being Scale (RPWS) were used for data collection. Statistical analysis involved the use of Multiple regression. Findings from the hypotheses indicated that, work-family conflict significantly influenced psychological well-being among police Officers in Makurdi metropolis. Work stress significantly influenced psychological well-being among police officers in Makurdi metropolis. Finally, the result showed that, work-family conflict and work stress had significant negative joint influence on psychological well-being among police Officers in Makurdi metropolis. Based on the findings, it was recommended that, Police Officers should be enlightened on how to manage work-family conflict and work stress. On policy basis, it was therefore recommended that government should evolve policies that are aimed at reducing work-family conflict and work stress among police Officers. Also, nongovernmental organizations with caring mind for the police Officers should help reduce work-family conflict and work stress, so as to enhance better policing by the officers. Finally, more researches should be encouraged on the subject matter for further identification of long term solutions to the problems affecting psychological well-being of police Officers in Makurdi metropolis in particular, and Nigeria at large.
\end{abstract}

Keywords: work-family conflict, work stress, demographic factors, psychological well-being, police Officers and metropolis. 


\section{INTRODUCTION}

Psychological well-being within the behavioural sciences is a concept that is use to determine the state of an individual in terms of perception, experience, feeling and cognitive state. The concept has attracted considerable attention of researchers in the twenty-first century (Archontakil, Lewis, \& Bates, 2012; Diener \& Seligman, 2002). According to Diener (1997) psychological well-being refers to how people evaluate their life in terms of cognition, emotion or feeling. It expresses the frequency with which people experience pleasant or unpleasant moods and emotions, which have a positive or negative effect. Thus, people experience level of subjective well-being even if they do not often consciously think about it, and the psychological system offers virtually a constant evaluation of what is happening to them.

Psychological well-being can also be defined in terms of internal experience of the respondents and perception of their lives (Harter, Schmidt, \& Keyes, 2002). Literatures on psychological well-being have progressed rapidly since the emergence of the field over five decades ago (Archontakil, Lewis, \& Bates, 2012). Also, recent surveys show how psychologists and other social scientists have taken huge steps in their understanding of the factors influencing psychological well-being (Christopher, 2015). Therefore, psychological well-being can be referred to as general term used by psychologists to explain the general condition of an individual or group of people, which includes psychological, social, economic, spiritual or medical state. Many studies found a rich and fulfilling social life and a network of close social support with family and friends as being strongly correlated with psychological well-being. A study of the happiest $10 \%$ of college students showed that those found to engage in large amounts of social activity were the happiest (Diener \& Seligman, 2002). Consistent with the conclusions from this study was the experiment conducted by Fleeson, Malanos and Achille (2002) where both extroverted and introverted college students were asked to record their activities and moods over a period of 3 weeks in a diary. The results showed that, both groups were happiest when engaged in 'extroverted' activities. Both of these studies support the theory that, social participation is a strong predictor of psychological well-being. Indeed, it is easy to see why extroverts have a predisposition to greater levels of psychological well-being, given their propensity to socialize more. However, this does not explain the findings of Diener, Sandvik, Pavot and Fujita (1992) which showed that, whether extroverts lived alone or with others, whether they had jobs which involved working with other people or not and whether they lived in rural or urban areas, extroverts were happier than introverts. This raises the question as to whether the social aspects that lead to greater experiences of positive affect have been over emphasized.

One variable that is found to be implicated in psychological well-being of police officers is Work-family conflict which is also described as an inter-role conflict (Greenhaus \& Beutell, 1985). Work-family conflict occurs when meeting the demands of a particular role is incompatible with full compliance with another role, thereby producing strain. Presently, a more contemporary view of the work and family interface is developing; one that is not limited to conflict, but allows for examination of how family and work domains can enhance or enrich one another (Greenhaus \& Parasuraman, 1999; Greenhaus \& Powell, 2006). Many researchers have examined work-family conflict and referred it to negative work-family spillover, workfamily interference and work-family tension (Greenhaus \& Parasuraman, 1999). Work-family conflict was originally seen as a one-dimensional construct (Greenhaus \& Parasuraman, 1999). Studies by Greenhaus and Beutel, (1985); Gutek, Searle, and Klepa, (1991) have suggested that conflict between work and family can originate sometime in domain. Now the reciprocal nature of the work-family conflict has been recognized. In other words, conflict can arise from work interfering with family or family interfering with work. Both work and family are central to one's life but these roles do not always readily reconcile, in particular when workers are 
faced with major stressors in the workplace and long working hours (Louw \& Viviers 2010), such as the police force. Work-family conflict has a significant influence on family distress, which is the experience of stress associated with one's family role. According to Mostert and Joubert (2005), balancing work and family life has become an increasing challenge for working individuals.

Studies have shown that, organizations continue to foster a high level of cognitive and emotional commitment amongst employees resulting in employees working extra or longer hours due to work demands (Lewis \& Cooper, 2005). This leads to higher stress which gets exacerbated by their family roles. As work-family conflict increases, so does the level of family distress. As one experiences conflict between his work and family roles, he or she is likely to have more distress at home, in trying to deal with the conflict that has arisen from any of the two roles (work or family). Police officers experience high stress levels, brutality, corruption and risk of suicide (Young, 2012) so it is imperative that their stressors are effectively managed. Comparing police force work with other occupations, Sever and Cinoglu (2010) considered police job to be highly stressful. They further argue that the families of the police officers also get affected by the stress that officers experiences. Work-family conflict antecedents include work role stressors, work-role involvement, work social support, work characteristics and personality (Michael, 2011).

Apart from stress arising from work-family conflict, police officers suffer from work stress. According to Christopher, (2014) work stress is the response people may have when presented with work demands and pressures that are not matched to their knowledge and abilities, which challenge their ability to cope. Police profession is meeting numerous of critical work problems which are described as having negative influence on officers' psychological wellbeing (Joseph (2015). On his part; (Christopher, 2015) added that: while handling the criminal offences, the police officers encounter violence, cruelty and indifference to the welfare of others. In one perspective they try to meet the conflicting demands of the public at the same time they face bureaucracy in their own organizations, internal politics and rigid traditional style of management.

Work stress is a critical factor in determining workers' health and psychological well-being. It is a phenomenon that has generated interest of researchers due to its negative perception and bio-medical effects on human behavioural manifestation. Stress has been described as a biochemical and behaviour reactions associated with fight or flight response (Joseph, 2015). Stress is scientifically used as a psychological precursor of illness; and serves as a catchall for anxiety, discomfort, and the likes. In some of the studies, it is identified that, being a police officer is a stressful job (Christopher, 2015). Police officers experiencing high levels of work stress, report a high incidence of physical syndrome and psychological problems that affect their psychological well-being (Joseph, 2015). Stress can be referred to as the psychological factor that is harmful to physical and psychological health and dangerous to individuals' psychological well-being. Many researchers found that such a long shifts, violence, traumatic events, murder, assault, and other inherent danger, organizational factors are some important factors that affects psychological well-being of police (Mohren, 2003; Ursin \& Eriksen, 2004). Police force is considered as one of the most stressful occupations, exposing staff to occupational, organizational, and personal stressors (Alexander, 1999; Paton \& Violanti, 1999; Anshel, 2000). Significant research findings have documented that prolonged stress has negative effects on individual health and psychological well-being (Mohren, 2003; Ursin \& Eriksen, 2004), as well as employees' attitudes towards the organization (Cropanzano, Rupp, \& Byrne, 2003). Among many professional adverse effects of work stress are job dissatisfaction, 
poor public relations, reduced productivity, absenteeism, and high staff turnover; adverse personal effects, anxiety, depression, and burnout (Gershon, 2002).

\section{STATEMENT OF PROBLEM}

Nigeria Police officers occupy a central role in protection of lives and properties, maintaining law and order as well as providing a safe and secure environment for Nigerians. Experience has shown that, officers are faced with a lot of challenges, in the course of carrying out their primary assignments. These challenges occur as a result of a sharp rise in insecurity across the country; whereby, officers are faced with cases of arm robbery, kidnappings, terrorism (Boko Haram insurgence/militancy), and religious/communal crisis among others.

Many officers share their time between family and work activities, since there is no one left behind as a permanent home maker. This trend has given birth to a situation known as workfamily conflict among Police officers (Soul, John \& Barnabas, 2014). Another problem police Officers faced in the discharge of their duties is work stress. Thus, Officers are faced with a lot of stress emanating from the demands of their work. These challenges has tendency to hamper the Officers' psychological well-being, as they struggle to cope with pressure from each angle (Saidu, 2013).

Consequences of these problems go beyond boundaries of the police circle. It affects every family, community and the country at large. Studies have linked negative effect on psychological well-being of police Officer to the sharp rise in incidences of extra-judicial killing of innocent citizens by the officers, unprofessional policing and lack of self confidence to combat crime (Pamson \& John, 2013). These problems increase day by day and even led to the order of the inspector general of police; Arase to subject police officers whose duty include carrying of fire arms to undergo psychological test and evaluation (Olabisi, 2016).

Finally, not much study of this nature were carried out in the study area therefore, the understanding of Work-family Conflict and Work Stress run the risk of becoming culturally biased. By conducting this study with Nigerian sample the researcher hopes to address this problem.

It was therefore hypothesized that:

i. There will be a significant negative influence of work-family conflict on psychological well-being among police officers in Makurdi metropolis.

ii. There will be a significant negative influence of work stress on psychological well-being among police officers in Makurdi metropolis.

iii. There will be a significant joint negative influence of work-family conflict and work stress on psychological well-being among police officers in Makurdi metropolis.

\section{Design}

\section{METHOD}

This study employed a cross-sectional survey design to elicit information from respondents on the influence of work-family conflict and work stress on the psychological well-being among police officers in Makurdi Metropolis Benue State. This research design enabled the researcher elicited information from respondents (police officers) cutting across different sex, age, rank, marital status, education, and income working in Makurdi Metropolis, which adequately measured the study variables. The independent variables in this study are work-family conflict and work stress while the dependent variable is psychological well-being. 


\section{Setting}

The study was conducted among police officers serving in Makurdi metropolis; a capital city of Benue state, located in central Nigeria along the Benue River; at latitude of $7,37^{\circ}$ and $7,47^{\circ} \mathrm{N}$; and longitude of 8,27 and 8,40 ${ }^{\circ}$ E. Benue State Police Command was established in 1976 (Nigeria Police Force, June, 2016). The command is made up of three Area Commands; Gboko Area Command, Otukpo Area Command and Makurdi Area Command. The study included officers of the state Headquarters, 13 Mobile Police Force, A division, B division, C division, D division and E divisional Police Headquarters within Makurdi metropolis respectively.

\section{Sampling}

A purposive sampling technique was used for the study. Purposive sampling is the procedure in which the investigator identifies individuals who are considered to be typical of the population and select them as the sample (Akinsola, 2005). Therefore the researcher recruited only Police Officers who volunteered within the study area.

\section{Sample Size Determination}

However, in order to determine sample size of the study, Taro Yamane's (1967) formula was used from the population of 2,450 police officers working in police formations within Makurdi metropolis (Nigeria Police Force, June, 2016).

Where:

$$
\mathrm{n}=\frac{\mathrm{N}}{1+\mathrm{N}}(\mathrm{e})^{2}
$$

$\mathrm{n}=$ the sample size

$\mathrm{N}=$ the population size

$\mathrm{E}=$ the tolerable sample error $(0.05)$

Therefore substituting the formula stated above

$$
\begin{aligned}
& \mathrm{n}=\frac{2450}{1+2450(0.05)^{2}} \\
& \mathrm{n}=\frac{2450}{1+2450(0.0025)} \\
& \mathrm{n}=\frac{2450}{1+6.125} \\
& \mathrm{n}=\frac{2450}{7.125} \\
& \mathrm{n}=346
\end{aligned}
$$

\section{Participants}

The participants for this research cut-across Police Officers of different sex, age, rank, marital status, education and income, in Makurdi metropolis, which were purposely drawn from the state headquarters, 13 Mobile Police Force, A division, B division, C division, D division and $\mathrm{E}$ divisional police headquarters. The size of the population is 2,450 Police Officers from all police formations within Makurdi metropolis, while 346 were sample for the study.

\section{Instruments}

Data for this study were collected using three standardized research instruments thus: 
i. Work- Family Conflict Scale (WFCS)

ii. Workplace Stress Scale (WSS)

iii. Ryff's Psychological Well being Scale (RPWS)

\section{i. Work-Family Conflict Scale (FWCS)}

was developed by Vermeulen and Sonubi (2015). Work-Family Conflict Scale (FWCS) is 15 item scale designed to measure work-family pressure among workers. The scale is scored on a 5 -point Likert-type scale $(1=$ strongly disagree, $2=$ disagree, $3=$ undecided, $4=$ agree and $5=$ strongly agree). The scale originally has a test-retest reliability coefficient of between .68 and .93 (Vermeulen \& Sonubi, 2015).

\section{ii. Workplace Stress Scale}

was developed by Marlin and American Institute of Stress (Yonkers, 2001) Workplace Stress Scale is 8-item scale designed to measure work stress among employees. The scale is scored on a 5 -point Likert-type scale ranging from $1=$ Never, $2=$ Rarely, $3=$ Sometimes, $4=$ Often to 5 $=$ Very Often. Total score of 15 or lower indicate that stress is not a problem. Total score 16 to 20 is fairly low stress level. Total score 21-25 indicate moderate stress. Total score 26-30 indicate severe level of stress. The wrong time, and might benefit from counseling. Total score 31- 40 (2\%) show that stress level is potentially dangerous. The instrument has overall norms: 18.4, for Men: 18.6; Women: 18.1. Ages18-34: 17.6; Ages 35-49: 19.2; Ages 50+.

\section{iii. Ryff's Psychological Well being Scale (RPWS)}

is a widely-used instrument designed by Ryff (1989). A 62-item Ryff's Psychological Well-Being Scales (RPWS) was designed to measure six dimensions of psychological well-being which include: a positive attitude toward oneself and one's past life (self-acceptance), high quality, satisfying relationships with others (positive relations with others), a sense of selfdetermination, independence, and freedom from norms (autonomy), having life goals and a belief that one's life is meaningful (purpose in life), the ability to manage life and one's surroundings (environmental mastery), and being open to new experiences as well as having continued personal growth (personal growth).

Psychological Well-Being Scales (RPWS) is scored based on 4-point likert scale of strongly agree $=4$; agree=3; disagree $=2$ and strongly disagree $=1$. However, items 1, 6, 17, 23, 34, 42 and 57 are scored in a reverse order. The total score for each respondent is arrived at by sum up sores for each item.

Psychological Well-Being Scales (RPWS) was originally validated on a sample of 321 welleducated, socially connected, financially-comfortable and physically healthy men and women (Ryff 1989). The internal consistency coefficients were quite high (between 0.86 and 0.93) and the test-retest reliability coefficients for a subsample of the participants over a six week period were also high (0.81-0.88).

\section{Pilot Study}

In order to ensure reliability and validity of instruments used on indigenous and study sample, the instruments were subjected to pilot study using police Officers in Otukpo Area Command, Benue State. For this pilot study, a total number of 103 copies of instruments were administered to the participant using conveyance sampling in which each officer were contacted while on duty to response voluntarily. Out of these number distributed only 97 were returned representing the return rate of $99.9 \%$. 6 copies representing $6.2 \%$ were not returned. Result indicated the following: 
In the current study the Work-Family Conflict Scale has a Cronbach's alpha of .83 and total variance of 67.506 indicating that the test items are highly reliable and validly measures $67.5 \%$ of work-family conflict among police officers

In the current study the Work Place Scale has a Cronbach's alpha of .62 and total variance of 52.179 indicating that the test items are highly reliable and validly measures $52.2 \%$ of work place stress among police officers

In the current study the Rift Psychological Well-being Scale has a Cronbach's alpha of .87 and total variance of 67.506 indicating that the test items are highly reliable and validly measures $76.9 \%$ of psychological wellbeing among police officers. The six dimensions of the scale have Cronbach's Alpha .72, .66, .78, .69, .72 and .70 for autonomy, environmental mastery, personal growth, positive relations, purposive in life and self-acceptance

\section{Procedure}

In the course of the research, the researcher personally administered the questionnaire to officers of the Nigeria police force within Makurdi metropolis purposively; state Headquarter, 13 police mobile force, A division, B division, $\mathrm{C}$ division, $\mathrm{D}$ division and $\mathrm{E}$ divisional police headquarters respectively. The researcher first took a letter of introduction from the Department of Psychology to the Commissioner of Police Benue state command Makurdi. Approval was given and the researcher established rapport with the respondents; after which their consent was sought. Finally, questionnaires were administered to them with assurance that the information will be handled with confidentiality.

\section{Data Analysis}

The researcher used 21 version of statistical package for social sciences (SPSS) to analyze the data in which the correlation analysis was first used to find out the reliability and validity of the instruments. The final statistics used was Regression analysis of variance. Multiple Regressions were chosen to test whether there will be a significant negative influence of workfamily conflict on psychological well-being among police officers in Makurdi metropolis, whether there will be a significant negative influence of work stress on psychological wellbeing among police officers in Makurdi metropolis and whether there will be a significant joint negative influence of work-family conflict and work stress on psychological well-being among police officers in Makurdi metropolis.

\section{RESULTS}

This study examined the influence of work-family conflict and work stress psychological wellbeing among police Officers in Makurdi Metropolis. In regards to this, data were collected, tested and this chapter presents results derived from data analysis according to the stated hypotheses.

\section{Hypotheses Testing}

Hypotheses I: This hypothesis states that there will be a significant negative influence of workfamily conflict on psychological well-being among police Officers in Makurdi metropolis.

This hypothesis was tested using Regression Analysis and the results are tabulated and interpreted as shown below. 
Table 1: Multiple regression showing the negative influence of work-family conflict on psychological well-being among police Officers in Makurdi Metropolis

\begin{tabular}{|c|c|c|c|c|c|c|}
\hline Variables & $\boldsymbol{R}$ & $\boldsymbol{R}^{2}$ & $\boldsymbol{F}$ & $\beta$ & $T$ & $\boldsymbol{P}$ \\
\hline \multicolumn{7}{|l|}{ Psychological } \\
\hline Wellbeing & .228 & .052 & 18.890 & & 25.385 & .000 \\
\hline Constant & & & & -.228 & -4.346 & .000 \\
\hline \multicolumn{7}{|l|}{ Work-family Conflict } \\
\hline \multicolumn{7}{|l|}{ Autonomy } \\
\hline Constant & .138 & .019 & 6.652 & & 14.809 & .000 \\
\hline Work-family Conflict & & & & -.138 & -2.579 & .010 \\
\hline \multicolumn{7}{|l|}{ Environmental } \\
\hline Mastery & .221 & .049 & 17.701 & & 18.188 & .000 \\
\hline Constant & & & & -.221 & -4.207 & .000 \\
\hline \multicolumn{7}{|l|}{ Work-family Conflict } \\
\hline \multicolumn{7}{|l|}{ Personal Growth } \\
\hline Constant & .207 & .043 & 15.405 & & 17.864 & .000 \\
\hline Work-family Conflict & & & & -.207 & -3.925 & .000 \\
\hline \multicolumn{7}{|l|}{ Positive Relations } \\
\hline Constant & .252 & .064 & 23.356 & & 21.340 & .000 \\
\hline Work-family Conflict & & & & -.252 & -4.833 & .000 \\
\hline \multicolumn{7}{|l|}{ Purpose in Life } \\
\hline Constant & .136 & .019 & 6.489 & & 16.778 & .000 \\
\hline Work-family Conflict & & & & -.136 & -2.549 & .011 \\
\hline \multicolumn{7}{|l|}{ Self-acceptance } \\
\hline Constant & .041 & .002 & .587 & & 14.756 & .000 \\
\hline Work-family Conflict & & & & -.041 & -.766 & .444 \\
\hline
\end{tabular}

Criterion Variable: Psychological Well-being

The results presented in table 1 above revealed that there was a significant negative influence of work-family conflict on psychological well-being of police Officers in Makurdi metropolis $(R$ $=.228$ and $R^{2}=.052(F(1,344)=18.890, t=25.385, p<.05)$. This means that work-family conflict contributes $52.0 \%$ to changes in psychological well-being of police Officers. This finding implies that higher level of work-family conflict is likely to leads to lower level of psychological well-being among police Officers. Therefore, this research hypothesis has been confirmed and the null hypothesis rejected.

The results presented in table 1 with regards to dimensions of psychological well-being indicated that there was a significant negative influence of work-family conflict on autonomy of police Officers $(\beta=-.138, p<.010)$. The result further showed that work-family conflict contributes $19.0 \%$ to changes in autonomy of police Officers. This finding implies that higher level of work-family conflict leads to lower level of police Officers' autonomy.

The results presented in table 1 further showed that there was a significant negative influence of work-family conflict on environmental mastery of police Officers $(\beta=-.221, p<.000)$. The result also indicated that work-family conflict made a significant contribution of $49.0 \%$ to changes in environmental mastery of police Officers. This finding implies that higher level of work-family conflict leads to decline in environmental mastery of police Officers.

The results presented in table 1 in respect of hypothesis I indicated that there was a significant negative influence of work-family conflict on personal growth of police Officers $(\beta=-.207, p<$ 
.000). The result also showed that work-family conflict contributes $43.0 \%$ to decline in personal growth of police Officers. This finding implies that higher level of work-family conflict is likely to affect personal growth of police Officers negatively.

Similarly, the results presented in table 1 in respect of hypothesis I showed that there was a significant negative influence of work-family conflict on positive relations among police Officers $(\beta=-.252, p<.000)$. The further means that work-family conflict contributes $43.0 \%$ to decline in positive relations of police Officers. This finding implies that higher level of workfamily conflict is likely to affect positive relations of police Officers negatively.

Furthermore, the results presented in table 1 in respect of hypothesis I indicated that there was a significant negative influence of work-family conflict on purpose in life among police Officers $(\beta=-.136, p<.011)$. The result further showed that work-family conflict contributes $19.0 \%$ to decline in purpose in life of police Officers. This finding implies that higher level of work-family conflict is likely to affect purpose in life of police Officers negatively.

Finally, the results presented in table 1 in respect of hypothesis I indicated that there was no significant negative influence of work-family conflict on self-acceptance among police Officers $(\beta=-.041, p>.444)$. The result further indicated that work-family conflict insignificantly contribute $2.0 \%$ to decline in self-acceptance of police Officers. This finding implies that higher level of work-family conflict is less likely to affect self-acceptance of police Officers negatively.

Hypotheses II: This hypothesis states that there will be a significant negative influence of work stress on psychological well-being among police Officers in Makurdi metropolis.

This hypothesis was tested using Regression Analysis and the results are tabulated and interpreted as shown below. 
Table 2: Multiple regression analysis showing the negative influence of work stress on psychological well-being among police Officers in Makurdi Metropolis.

\begin{tabular}{|c|c|c|c|c|c|c|}
\hline Variables & $\boldsymbol{R}$ & $\boldsymbol{R}^{2}$ & $F$ & $\beta$ & $T$ & $\boldsymbol{P}$ \\
\hline \multicolumn{7}{|l|}{ Psychological } \\
\hline Wellbeing & .223 & .050 & 17.975 & & 25.115 & .000 \\
\hline Constant & & & & -.223 & -4.240 & .000 \\
\hline \multicolumn{7}{|l|}{ Work Stress } \\
\hline \multicolumn{7}{|l|}{ Autonomy } \\
\hline Constant & .125 & .016 & 5.464 & & 15.633 & .000 \\
\hline Work Stress & & & & -.125 & -2.337 & .020 \\
\hline \multicolumn{7}{|c|}{ Environmental } \\
\hline Mastery & .179 & .032 & 11.369 & & 18.472 & .000 \\
\hline Constant & & & & -.179 & -3.372 & .001 \\
\hline \multicolumn{7}{|c|}{ Work Stress } \\
\hline \multicolumn{7}{|c|}{ Personal Growth } \\
\hline Constant & .212 & .045 & 16.128 & & 19.201 & .000 \\
\hline Work Stress & & & & -.212 & -4.016 & .000 \\
\hline \multicolumn{7}{|c|}{ Positive Relations } \\
\hline Constant & .256 & .086 & 24.144 & . & 22.898 & .000 \\
\hline Work Stress & & & & -.256 & -4.914 & .000 \\
\hline \multicolumn{7}{|c|}{ Purpose in Life } \\
\hline Constant & .110 & .012 & 4.230 & & 17.507 & .000 \\
\hline Work Stress & & & & -.110 & -2.057 & .040 \\
\hline \multicolumn{7}{|c|}{ Self-acceptance } \\
\hline Constant & .111 & .013 & 4.247 & & 17.347 & .000 \\
\hline Work Stress & & & & -.111 & -2.061 & .040 \\
\hline
\end{tabular}

Criterion Variable: Psychological Wellbeing

The results presented in table 2 above showed that there was a significant negative influence of work stress on psychological well-being of police Officers in Makurdi metropolis $(R=.223=$ $R^{2}=.050(F(1,344)=17.975, t=25.115, p<.05)$. This means that work stress contributes $50.0 \%$ to changes in psychological well-being of police Officers. This finding implies that higher level of work stress is likely to leads to lower level of psychological well-being among police Officers. Therefore, this research hypothesis has been confirmed and the null hypothesis rejected.

The results presented in table 2 with regards to dimensions of psychological well-being showed that there was a significant negative influence of work stress on autonomy of police Officers $(\beta=-.125, p<.020)$. The result further means that work stress contributes $18.0 \%$ to changes in autonomy of police officers. This finding implies that higher level of work stress leads to lower level of police Officers' autonomy.

The results presented in table 2 further showed that there was a significant negative influence of work stress on environmental mastery of police Officers $(\beta=-.179, p<.001)$. The result further indicated that work stress made a significant contribution of $32.0 \%$ to changes in environmental mastery of police Officers. This finding implies that higher level of work stress is leads to decline in environmental mastery of police Officers.

Similarly, the results presented in table 2 in respect of hypothesis II indicated that there was a significant negative influence of work stress on personal growth of police Officers $(\beta=-.212, p<$ $.000)$. The result further means that work stress contributes to $45.0 \%$ decline in personal 
growth of police Officers. This finding implies that higher level of work stress is likely to affect personal growth of police Officers negatively.

The results presented in table 2 in respect of hypothesis II indicated that there was a significant negative influence of work stress on positive relations among police Officers $(\beta=$ $.256, p<.000$ ). The result further indicated that work stress contributes $86.0 \%$ decline in personal growth of police officers. This finding implies that higher level of work stress is likely to affect positive relations of police Officers negatively.

The results presented in table 2 in respect of hypothesis II indicated that there was a significant negative influence of work stress on purpose in life among police Officers $(\beta=-.110$, $p<.040$ ). The result further means that work stress contributes $12.0 \%$ to the decline in purpose in life of police officers. This finding implies that higher level of work stress is likely to affect purpose in life among police Officers negatively.

The results presented in table 2 in respect of hypothesis II indicated that there was a significant negative influence of work stress on self-acceptance among police Officers $(\beta=$ $.111, p<.040$ ). This result further showed that work stress significantly contributes $13.0 \%$ to the decline in self-acceptance of police Officers. This finding implies that higher level of work stress is likely to affect self-acceptance of police Officers negatively.

Hypotheses III: This hypothesis states that there will be a significant joint negative influence of work-family conflict and work stress on psychological well-being of police Officers in Makurdi metropolis.

This hypothesis was tested using Regression Analysis and the results are tabulated and interpreted as shown below. 
Table 3: Multiple regression analysis showing the negative joint influence of work-family conflict and work stress on psychological well-being among police Officers in Makurdi Metropolis.

\begin{tabular}{|c|c|c|c|c|c|c|}
\hline Variables & $\boldsymbol{R}$ & $\boldsymbol{R}^{2}$ & $\boldsymbol{F}$ & $\beta$ & $T$ & $p$ \\
\hline \multicolumn{7}{|l|}{ Psychological } \\
\hline Wellbeing & .278 & .077 & 14.358 & & 23.451 & .000 \\
\hline Constant & & & & -.175 & -3.203 & .001 \\
\hline Work-family Conflict & & & & -.167 & -3.061 & .002 \\
\hline \multicolumn{7}{|l|}{ Work Stress } \\
\hline \multicolumn{7}{|l|}{ Autonomy } \\
\hline Constant & .162 & .026 & 4.639 & & 13.465 & .000 \\
\hline Work-family Conflict & & & & -.109 & -1.942 & .053 \\
\hline Work Stress & & & & -.090 & -1.611 & .108 \\
\hline \multicolumn{7}{|l|}{ Environmental } \\
\hline Mastery & .249 & .062 & 11.354 & & 16.701 & .000 \\
\hline Constant & & & & -.183 & -3.318 & .001 \\
\hline Work-family Conflict & & & & -.121 & -3.193 & .029 \\
\hline \multicolumn{7}{|l|}{ Work Stress } \\
\hline \multicolumn{7}{|l|}{ Personal Growth } \\
\hline Constant & .258 & .067 & 12.231 & & 16.909 & .000 \\
\hline Work-family Conflict & & & & -.156 & -2.829 & .005 \\
\hline Work Stress & & & & -.162 & -2.951 & .003 \\
\hline \multicolumn{7}{|l|}{ Positive Relations } \\
\hline Constant & .313 & .098 & 16.653 & & 20.365 & .000 \\
\hline Work-family Conflict & & & & -.190 & -3.516 & .000 \\
\hline Work Stress & & & & -.196 & -3.623 & .000 \\
\hline \multicolumn{7}{|l|}{ Purpose in Life } \\
\hline Constant & .153 & .024 & 4.135 & & 14.976 & .000 \\
\hline Work-family Conflict & & & & -.113 & -2.001 & .046 \\
\hline Work Stress & & & & -.075 & -1.326 & .186 \\
\hline \multicolumn{7}{|l|}{ Self-acceptance } \\
\hline Constant & .111 & .012 & 2.125 & & 13.599 & .000 \\
\hline Work-family Conflict & & & & -.007 & -.124 & .902 \\
\hline Work Stress & & & & -.108 & -1.913 & .057 \\
\hline
\end{tabular}

Criterion Variable: Psychological Well-being

The results presented in table 3 above showed that there was a significant joint negative influence of work-family conflict and work stress on psychological well-being among police Officers $\left(R=.278=R^{2}=.077(F(2,343)=14.358, t=23.451, p<.05)\right.$. This means that workfamily conflict and work stress jointly contribute to $77.0 \%$ variations in psychological wellbeing of police officers. This finding implies that work-family conflict and work stress are likely co-determinant of lower level of psychological well-being among police Officers. Therefore, this hypothesis has been confirmed and the null hypothesis rejected.

The results presented in table 3 also showed that there was a significant negative joint influence of work-family conflict and work stress on autonomy of police Officers Work-family conflict $(\beta=-.109, p<.053)$ and Work stress $(\beta=-.090, p>.108)$. The result further means that work-family conflict and work stress jointly contribute $26.0 \%$ in decline of autonomy of police officers. This finding implies that higher level of work stress leads to lower level of police Officers' autonomy. 
The results presented in table 3 further showed that there was a significant joint negative influence of work-family conflict and work stress on environmental mastery of police Officers Work-family conflict $(\beta=-.183, p<.001)$ and Work stress $(\beta=-.121, p<.029)$. The result further showed that work-family conflict and work stress jointly made a significant contribution of $62.0 \%$ to changes in environmental mastery of police officers. This finding implies that the interplay of work-family conflict and work stress leads to decline in environmental mastery of police Officers.

The results presented in table 3 in respect of hypothesis III indicated that there was a significant joint negative influence of work-family conflict and work stress on personal growth of police Officers Work-family conflict $(\beta=-.156, p<.005)$ and Work stress $(\beta=-.162, p<.003)$ The result further indicated that work-family conflict and work stress jointly contribute $45.0 \%$ to decline in personal growth of police Officers. This finding implies that work-family and work stress are co-determinants of personal growth of police Officers.

The results presented in table 3 in respect of hypothesis III indicated that there was a joint significant negative influence of work-family conflict and work stress on positive relations among police Officers Work-family conflict $(\beta=-.190, p<.000)$ and Work stress $(\beta=-.196, p<$ $.000)$. The result also indicated that work-family conflict and work stress jointly contribute $86.0 \%$ to decline in personal growth of police Officers. This finding implies that the interplay of work-family conflict and work stress is likely to affect positive relations of police Officers negatively.

The results presented in table 3 in respect of hypothesis III indicated that there was a joint significant negative influence of work-family conflict and work stress on purpose in life among police Officers Work-family conflict $(\beta=-.113, p<.046)$ and Work stress $(\beta=-.075, p>.186)$. The result further means that work-family conflict and work stress jointly contribute $12.0 \%$ to decline in purpose in life of police Officers. This finding implies that the interplay of workfamily conflict and work stress is likely to affect purpose in life of police Officers negatively.

The results presented in table 3 in respect of hypothesis III indicated that there was no significant joint negative influence of work-family conflict and work stress on self-acceptance among police Officers Work-family conflict $(\beta=-.007, p>.902)$ and Work stress $(\beta=-.108, p<$ .057). This means that work-family conflict and work stress jointly contribute $13.0 \%$ to decline in self-acceptance of police Officers. This finding implies that the interaction between workfamily conflict and work stress is likely to affect self-acceptance of police Officers negatively.

\section{DISCUSSION}

Various hypotheses in relationship to the study were discussed in this section.

Hypothesis one was tested to find out if there will be a significant negative influence of workfamily conflict on psychological well-being among police officers in Makurdi metropolis. This hypothesis was confirmed, as the result of data analysis was enough to give statistical significance. The finding supports the work of John and Pius, (2015). According to them, workfamily conflict is considered as a major determinant of psychological well-being of every employee. Also that, the more problems or un-resolve conflict persist in work-place and home (family) the decrease an employee becomes in effectiveness and performance because of the negative effect it has over their psychological wellbeing. This finding is also in line with the work of Abraham (2012), whose study revealed that, psychological well-being of an employee depends on the softer link and resolving ability of conflict that exist between home and workplace. This leads to accept the fact that "psychological well-being of police officers should 
be view as the officer's satisfaction with job, co-workers, other job related aspect and satisfaction with domain such as family, spirituality, physical and psychological health" (Huhtala, \& Parzefall, 2007; Danana \& Griffin, 1999). This finding is instrumental to the society because in order to minimize factors affecting psychological well-being among police Officers, there should be reliable evidence as to the determinants of high or low state of psychological well-being. Accordingly and for preventive measures; when these factors are known as in the case of this study (work-family conflict), it is possible to minimize predictors of psychological well-being.

Hypothesis two sought to find out if work stress will significantly influence psychological wellbeing. Again, this hypothesis was confirmed. This finding agreed with the work of Adegoke (2014) whose work revealed that, work stress has become one of the major predictors of health, daily living and psychological well-being of police Officers. Liberman, Best, Metzler, Fagan, Weiss, and Marmar (2002) also holds that, work stress can be harmful to physical and psychological health and dangerous to psychological well-being. However, this finding disagreed with the finding of Ursin and Eriksen (2004) who indicated that, work stress is just a factor that can predict psychological well-being; only when paired with another factor. Also in line with this finding is the work of Mohren (2003) who noted that, long shifts, violence, traumatic events, murder, assault, and other inherent danger are occupational factors that affects psychological well-being of police Officers. The implication of this finding to the research is that, in order to minimize factors affecting psychological well-being of police Officers, there is a need for holistic understanding of these factors including work stress by both government (police management team) and the general public so as to minimize factors that can increase these factors.

Hypothesis three tried to find the significant joint negative influence of work-family conflict and work stress on psychological well-being among police officers in Makurdi metropolis. Again this hypothesis was accepted. This finding goes along that of Abraham (2012), who holds that, the psychological well-being of employee can be affected by joint contributions of problems arising, as a result of both work-family conflict and work stress. Other research works that are in line with this finding include the work of Sandiso and Nicole (2013) who noted that some factors like work-family conflict and work stress contributes in determining psychological well-being of workers. However, this finding goes contrary to the work of Allen, Herst, Bruck and Sutton (2000) who noted that work-family conflict and work stress does not predict psychological well-being among workers. His reason was based on the fact that workfamily conflict and work stress can predict psychological well-being, only when other factors relating to individual personality are involved. This finding is instrumental to police Officers and the society because it would help to ensure that, important factors leading to negative effect on psychological well-being of Officers are well identified and control.

\section{CONCLUSION AND RECOMMENDATIONS}

The main findings of the study are summarized as follows:

i. Work-family conflict was found to have significantly predicted psychological well-being among police Officers in Makurdi metropolis.

ii. Work stress also significantly influenced psychological well-being among police Officers in Makurdi metropolis.

iii. Work-family conflict and work stress were also found to have significant negative joint influence on psychological well-being among police Officers in Makurdi metropolis. 
Based on the findings of this study, the following recommendations were hereby advanced:

i. Police Officers should be enlightened on how to manage work-family conflict and work stress.

ii. On policy basis, it was therefore recommended that government should evolve policies that are aimed at reducing work-family conflict and work stress among police Officers.

iii. Also, nongovernmental organizations with caring mind for the police Officers should help reduce work-family conflict and work stress, so as to enhance better policing by the Officers.

iv. Finally, more researches should be encouraged on the subject matter for further identification of long term solutions to the problems affecting psychological well-being of police Officers in Makurdi metropolis in particular, and Nigeria at large.

\section{References}

Abraham, M. (2012). Psychological Work Environment, Organizational Justice and Work-family Conflict as Predictors of Malaysian Police Officers Psychological Well-being. Australia: Victoria University Press.

Adegoke, T. G. (2014). Effect of Occupational Stress on Psychological Well-being of Police Employees in Ibadan Metropolis. Ethopia: An International Journal of Multidisciplinary 8 (1), 302 - 320.

Akinsola, H. A. (2005). Research Methods in Medical and Nursing Practice. Ibadan: Collage Press Publishers Limited.

Allen, T. D., Herst, D. E., Bruck, C. S.,\& Suffon, M. (2000). Consequences Associated with Work - to - Family Conflict: A Review and Agenda for Future Research. Journal of Occupational Health Psychology. 3, 278 - 308.

Alexander, J. (1999). Police Psychological Burnout and Trauma. Psychological Aftermath Journal of Civilian Combat.12 (3), $54-64$.

Anshel, M. H. (2000). A Conceptual Model and Implications for Coping with Stressful Events in Police Work. Journal of Criminal Justice and Behaviour. (27) 3, $375-400$.

Archontakil, A., Lemis, J., \& Bates, K. (2012). Veersrils of Records Online: Personality and Individual Differences. Journal of Personality. (2) 81, 223-244.

Christopher, A. L. (2014). Work-Family Conflict, Psychological Well-Being, Satisfaction and Social Support: a Longitudinal Study in New Zealand. Journal of Equal Opportunities International 23 (4), 26 - 56.

Christopher, J. B. (2015). Effect of Job Stress on Psychological Well-being among Police Officers in Plateau Metropolis. Jos: Cholom Printers.

Cropanzano, R., Rupp, D. E., \& Bryne. G. (2003). The Relationship of Emotional Exhaustion to Work Attitudes, Job Performance, and Organizational Citizenship Behavior. Journal of Applied Psychology, 88 (1), 160 - 169.

Danana, K., \& Griffin, R. W. (1999). Health and Well-Being in the Workplace. A Review and Synthesis of the Literature. Journal of Management. 25 (2), 357 - 384.

Diener, E. (1997). Introduction of Special Section on the Structure of Emotion. USA: Journal of Personality and Psychology 76(2) $803-804$

Diener, E., Sandvik, E., Pavot, W., \& Fujita, F. (1992). Extraversion and Subjective Well-Being in a U.S. National Probability Sample. Journal of Research in Personality, 26, 205-215.

Diener, E., \& Seligman, M.E.P. (2002). Very Happy People. Psychological Science. Journal of Research in Personality 13 (1), 81-84.

Fleeson, W., Malanos, A., \& Achille, N. (2002). An Intra-Individual Process Approach to the Relationship between Extraversion and Positive Affect: Is Acting Extraverted as 'Good' as being Extraverted? Journal of Personality and Social Psychology, 83, 1409-1422.

Gershon, R. (2002). Work Stress in Aging Police Officers. Journal of Occupational and Environmental Medicine 44(2), 160.

Greenhaus. J. H.,\& Beutell, N. (1985). Sources of Conflict between Work and Family Roles. New-York: Header Publishers.

Greenhaus, J. H., \&Parasuraman. S. (1999). Research on Work, Family and Gender: Current Status and Future Directions. In G. N. Powell, (Ed). Handbook of Gender and Work (391-412). Newbury parkica: Sage Publishers. 
Greenhaus, J. H., \& Powell, G. N. (2006). When Work and Family Collide: Deciding Between Competing Role Demands, Organizational Behavior and Human Decision Processes. Journal of Organizational Behavior 90, 291 303.

Gutek, B. A., Searle, S.,\& Klepa, L. (1991). Rational Versus Gender Role Explanations for Work-family Conflict. Journal of Applied Psychology, 76, 560 - 568.

Harter, J. K., Schmidt, F. L.,\& Keyes, C. L. (2002). Well-being in the Workplace and its Relationship to Business Outcomes: A Review of the Gall up Studies. In C. L. Keyes, \& J. Haidt (Eds), Flourish: The Positive Person and the Good Life (205 - 224). Washington D.C: American Psychological Association.

Huhtala, H., \& Parzefall, M. F. (2007). A Review of Employee Well-being and Innovativeness: An Opportunity of a Mutual benefit. Journal of Creativity and Innovation Management, 16, 299 - 306.

Joseph, A. (2015). Exposure to Duty - Related Incident Stressors in Urban Fire Fighters and Paramedics. Journal of Traumatic Stress. 1 (4), 821 - 828.

John, A. S., \& Pius, K. (2015). Discriminate Validity: Osychological Well-being Measures. Journal of Personality and Social Psychology, (14) 71, 616-628.

Lewis, S., \& Cooper, C. L. (2005). Stress into Earner Couples and Stage in the Life Circle. Journal of Occupational Psychology, 60, 289 - 303.

Liberman A., Best S., Metzler T., Fagan J., Weiss D., \& Marmar, C. (2002). Routine Occupational Stress and Psychological Distress in Police. Policing: An International Journal of Police Strategies and Management, 25(2), 421-439.

Louw, B.,\& Viviers, R. (2010). Work and Family Variables, Entrepreneurial Career Success, and Psychological WellBeing. Journal of Vocational Behavior, 48, 275-300.

Michael, J. (2011). Antecedents of Work-family Conflict: : Amela-Analytic Review. Journal of Organizational Behaviour. 32, $689-725$.

Mostert, K., \& Jourbert A. F (2005). Job Stress Burnout and Coping Strategies in the South African Police Service. South African Journal of Economic and Management Sciences, 8 (1), 39-53

Mohren, D. C (2003). Common Infections and the Role of Burnout in a Dutch Working Population. Journal of Psychosomatic Research, 55(3), 201 - 208.

Nigeria Police Force, (2016). Department of Finance and Administration. State Headquarters, Makurdi.

Olabisi, A. (2016). The Combination Feeling and Good Functioning. Akure: FUTA press.

Pamson, A.,\& John, D. (2013). Predictors of Nigerian Employee Psychological Well-being. Jos: Katako Printing Press.

Paton, D., \& Violanti, J. M. (1999). Long - Term Exposure to Stress and Trauma: Addiction and Separation issues in Police officers. In G.M. Hubermann (Ed), Looking Back and Moving Forward: 50 Years of New Zealand Psychology, (123-133). Wellington: New Zealand Psychological Society Press.

Ryff, C. (1989). Ryff's Scale of Psychological Well-Being: Explorations on the Meaning of Psychological well-Being. Journal of Personality and Social Psychology 58,1069-1081

Saidu. U. (2013) Occupational Stress and Psychological Well-being in Nigeria. Journal of Research in National Development. (4) 8, 1 -12.

Sandiso , B. \& Nicole, D. (2013). Conscientiousness, Work Family Conflict and Psychological well-being amongst Police Officers in Alice, South Africa. Kamla Journal of Psychology, 4(1), 1-8

Saul, B. John, L., \& Barnabas, D. (2014). The Relationship Between Work-Family Enrichment and Optimism and their Influence on Psychological Well-Being. New-York: Available from: <http: 11creepingsharia.com. Accessed on $20^{\text {th }}$ March 2016

Sever, G. \& Cinoglu, B. (2010). Optimism, Coping, and Health: Assessment and Implications of Generalized Outcome Expectancies. Journal of Health Psychology, 4, 219- 247.

Ursine, H. \& Erisksen, H.R. (2004). The Cognitive Activation Theory of Stress: Psychoneurotic-Doctrinology, Journal of Physiological Psychology 29(5), 567 - 592

Vermeulen, P. L., \& Sonubi, A. O. (2015). Developing an Instrument of Assess Work-Family Conflict Scale: Resources Needed by Woman Managers in South Africa. African Journal of Business Management, 9(4), $170-185$.

Yamani, T. (1967). Statistics: An introductory Analysis, 2nd ED. New-York: Hamper and Raw Publishers. 
Sunday, S., Terzungwe, A. S., Okhakhume, S., \& Daudu, D. A. (2017). Influence of Work-Family Conflict and Work Stress on the Psychological WellBeing among Police Officers in Makurdi Metropolis. Advances in Social Sciences Research Journal, 4(17) 76-92.

Young, K. (2012). Supervising Police Personnel. New Jersey: Pearson Prentice Hall.

Yonkers, N. Y. (2001). Workplace Stress Scale. USA: Marlin Company Publishers 